
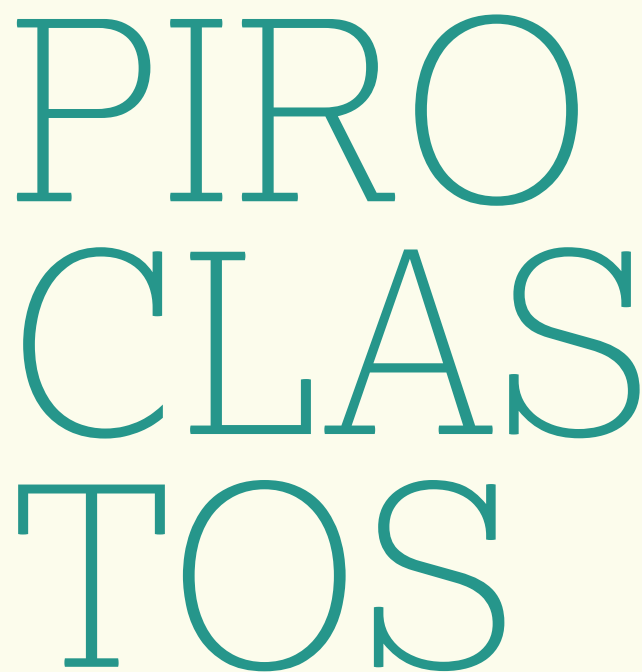

Do grego piro + klastós, -é, -ón.

Fragmentos de fogo expelidos durante a erupção e que solidificam. 



\section{QUATRO POEMAS}

- MICHELE SANTOS

\section{Poesia nunca servil para nada ${ }^{1}$}




\section{O SANGUE TEM SOM VERMELHO}

Entrepernas as penas que nunca tiveram das bruxas queimadas em público Não. Pedi foi cruz não, seu moço, perdi foi muito. Nem teve ganhado pr'além da garantia de troca entre minhas aparecências e o ângulo das minhas pernas abertas sem a essência píscea

da boceta limpa

dos ardis químicos

a limpeza higiênica dos teus fármacos

é o higienismo bárbaro da classe - idade -média

não quero o mínimo senão o máximo

Entrementes, mente a história

Construída sobre o registro das glórias bélicas, das guerras fálicas, dos falos tétricos, dos obstétricos mistérios bíblicos do nascimento do mundo. Imunda, tua boca morde minha liberdade mas não mastiga minha fúria que inunda úmida a garganta seca num grito rouco estrondo lírico pros teus ouvidos moucos estado... líquido pro teu peito sólido onde só cabe o código dos arbítrios mortos e matam as fêmeas que abortam os fetos no calabouço do quarto dos fundos no calaboca do médico público enquanto o sangue cai do útero a litros

Entretanto, me tonteio trôpega entre tantos outros Que só enxergam espelho e não veem as mortas Mulheres rotas muitas todas escondidas por entre As rotas das quebradas tortas da cidade monstra Que engole os ventres e esconde os vermes que Espancam as donas das casas as donas das ruas 
as mães de família, roxas, não comem a margarina da propaganda do intervalo da novela - sobre o pão que o diabo amassou Espalham estatística

Entretanto, uma voz que declama e reclama E clama contra o retrocesso do processo da vida Há tanta câmara, há pouca cama, haja cana pr'aguentar Os dias de lama, não sou a dama quiçá a ama Seilá a puta a louca a desvalida boca que vomita essa comida vencida que me alimenta o cotidiano e os olhos chibatas dos juízes morais das ruas essa voz essa voz essa voz [escuta quando essa voz se gastar até o estouro das cordas saberei muda que não vivi em vão

\section{Entrepernas}

Entrementes

Entretanto

Entretodas

O mesmo passo:

Contra os nós -

derrubamos muros

construímos laços

uníssonas. 


\section{NOBILÍSSIMO}

Se a wislaya nascesse no brasil

Se a wislaya tecesse poema no brasil

Se a wislaya tecendo poema no brasil não fosse bonita

Se a wislaya parindo poema no brasil não morasse no centro

Se a wislaya criando poema no brasil não fosse bem-relacionada

Se a wislaya forjando poema no brasil não fosse amiga do cara da editora que [vende pra saraiva

Se a wislaya escrevendo poema no brasil existisse ela não existiria sendo

[wislaya szymborszka

Talvez bordadeira

Poeta, ainda. 


\section{MMXVI}

Oh, sabe quê?

\section{Devíamos}

era levantar cedo, recolher os copos

Estancar os tragos, remendar as trincas

Devíamos começar a correr, fazer ioga

estabilizar o triglicérides -

Devíamos

nos descobrir, praticar o tantra,

Fazer juntos a janta

Com os orgânicos da varanda

plantados a quatro-mãos,

um coração

à esquerda dos narcisos brancos

no fundo da casa de quintal

e viver assim zen

e saber viver sem

açúcar, ansiolíticos, ressacas, brigas, gordura trans, lactose, nicotina, boletos de consumo, holerites, tevê, sódio, ódio, símiles, ismos, rebites, arroubos, dramas, fobias, seriados em pacote, pânicos insumos do cão por que a gente vende a alma pra justiçar a terra que pisa?

o ar - é de graça, ainda?

[Essa querência pra pássaro é que me anda aziando.

Oh. Sabe quê?

Devíamos era juntar a gente tudo

Dinamitar a porra toda

- do lado de lá. 


\section{REQUIÉM}

às manhãs do outono último. e algumas noites

estive concisa esses dias (meses? anos?)

estive luz de lâmpada

[halógena

pr'evitar o calor dos ânimos. não me salvou

do frio dum cano na cara

tampouco da cara na

lama. estive fio. estive lâmina.

estive choro, ex-tive chuva.

estou dopada.

estive estaca, estive estanque, estive estiva quando o mar morria.

[trabalhei com pescaria

no deserto até $a$

estreia aos olhos dum pacífico revoltoso

estourando as rochas do litoral quando

cê me cerzia de volta os estragos

como a velh'avó cozia os retalhos de fuxico

pras colchas das tias de minha infância

estive estranha. estou entranha. restou ex-punk minha alma Espanca.

entrou o silêncio berrando à precisão doutras vias -

estribo pra contenção das falhas

estrobo latejando os olhos-fardo

na esquina do peito é que os erros me acertam

não há esquiva pra mira fina:

o que me greta é o meu garbo.

[donde tecer a escrita . terço,

no mais, estar o que sou - isto:

balé bêbado; seguir a dançar só - doidivana - dois pés esquerdos

[go go gO

as minas terrestres delicadamente pousadas por estratégicas

mãos humanas no solo cotidiano das iras

estão cobertas de folhagem, estrume

e razão

na seção dos comentários 
[sempre preferi passar ao largo que passar por cima.

estatelo em stand etéreo. estéril, dez mg/dia, dês

que o mundo estorva a impaciência dos ansiosos crônicos

eles viram-se em diagnosticados mansos

estuque de parede murcha, esdrúxula, estúpida

[dócil.

[boa pra montaria e carga. cavala, jumenta, jagunça

[cidadã

só esviscerado o estômago externa o que nos humaniza:

víscera. bílis,

[ego

quando era aquele onze de março a morte chegando pertinha pensei num

[átimo que ser a porra

duma poeta morta num canto esquecido da zona última da província talvez me

[traria mais likes e

algum sucesso póstumo -

o caso é que tenho preguiça de morrer. 
MICHELE SANTOS - Michele Santos nasceu de inverno na metrópole paulistana e vive a buscar primaveras nos entremeios do cinza. É educadora nas redes públicas municipal e estadual de ensino de São Paulo e co-organizadora do Sarau Sobrenome Liberdade, na região do Grajaú/SP. Já foi publicada nas antologias Antes de ser um manifesto (publicação independente), Poesia na Faixa (Edições Tietê), 180 gramas (publicação independente ganhadora do PROAC), nas revistas Transvista, Gente de Palavra e Raimundo. 